Article

\title{
Biological Hotspot of Ichthyoplankton in The Estuarine Environment Timbulsoko Village, Demak
}

\author{
Hanityo Nugroho ${ }^{1, *}$, Sutrisno Anggoro ${ }^{2}$ and Ita Widowati ${ }^{2}$ \\ 1 Faculty of Fisheries and Marine Science, Departement of Marine Science, Master Program, \\ Diponegoro University, Indonesia; hanityonugroho@gmail.com \\ 2 Faculty of Fisheries and Marine Science, Departement of Marine Science, Diponegoro \\ University, Indonesia; mikundip@students.undip.ac.id \\ 2 Faculty of Fisheries and Marine Science, Departement of Marine Science, Diponegoro \\ University, Indonesia; ita_jusup@yahoo.co.id \\ * Correspondence: hanityoadinugroho@students.undip.ac.id \\ Received: date; Accepted: date; Published: date
}

Abstract: Biological Hotspot research of fish larvae in estuarine waters of Timbulsoko Village, Demak was conducted in April-June 2019 in Timbulsoko Village. Timbulsloko has fertile waters because many fishermen make this location as a fishing ground area. Timbulsloko has the potential to become a nursery ground area and feeding ground for fish due to natural mangrove habitat but the abrasion disaster resulted in the degradation of the nursery ground habitat for early stage fish. The results showed that fish larvae caught in the waters of Timbulsloko Village consisted of 13 families. The composition of the types of fish larvae caught are Mugilidae, Siganidae, Gobiidae, Leiognathidae, Scatophagidae, Chanidae, Latidae, Engraulidae, Gerreidae, Carangidae, Bagridae, Sillaginidae, Ambassidae. The most common types of fish larvae are Ambassidae fish larvae, which are $46.98 \%$, while the least caught are Carangidae fish larvae, Sillaginidae which is $1.01 \%$. The largest abundance of fish larvae is 428,271 ind / $\mathrm{m} 3$ found at D2P2, while the abundance of fish larvae is at least at E1P1270 point with an abundance value of 51,498 ind / m3. The similarity of ecological habitat values at D2P2 and A2G1 points based on PCA analysis and the similarity of contours from spatial depth interpolation indicate the biological hotspot in the mangrove waters of Timbulsloko Village.

Keywords: Diversity; Ecology; Fishes; Geoscience 


\section{Introduction}

Bioecology in fisheries studies about the relationship between fish and the aquatic environment as a natural habitat for fish. The concept of hotspots in fisheries is part of bioekology itself, but this term is better known as the biological hotspot in the field of earth science (geoscience). Biological hotspots are an area of concentration of biological life due to environmental factors, natural structures and productivity of an ecosystem [1]. Hotspots are a radical aspect to identify conservation areas and spatial resource management strategies. The intertidal zone as a meeting area between two ecosystems is a productive area which results in high biodiversity of the biota, besides that the risk of habitat degradation is also very high because the interaction of two ecosystems that continues to occur results in erosion, sedimentation, exploitation, etc. [2]-[4]. In-depth studies for this area are considered very important to prevent damage that occurs considering the high potential of environmental degradation caused by humans and nature. The Intertidal Zone of the village of Timbulsloko began to experience the effects of abrasion which developed rapidly since 2000 due to changes in the flow of ocean currents due to development and as a wave and rob barrier that occurred in the coastal city of Semarang [5], [6]. The purpose of this study was to inventory data on early stage fish in the Timbulsloko waters.

\section{Materials and Methods}

This research was carried out in the intertidal zone of Timbulsloko Village, Demak. Primary data is obtained by conducting direct observation in the field during April - June 2019

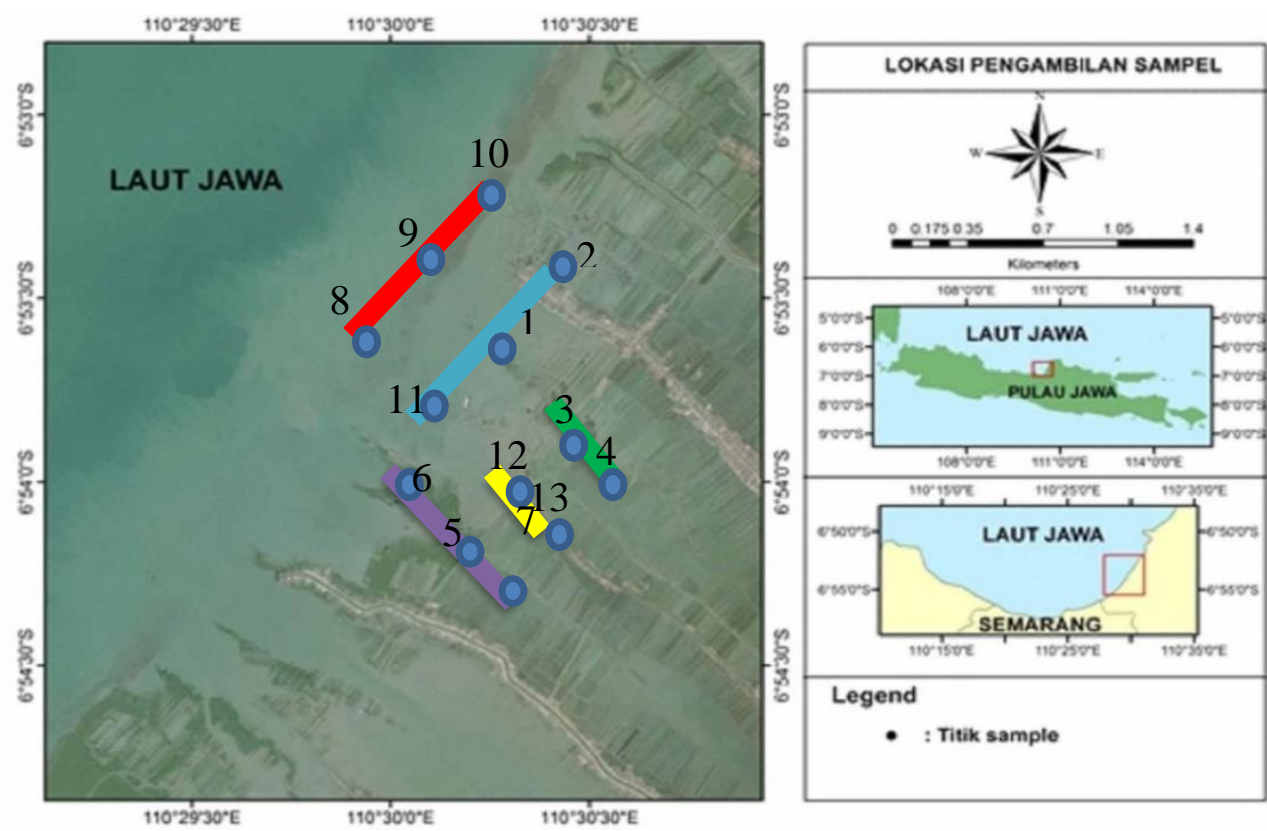

(a)

Figure 1. Research station on R (Red), LB (Light Blue), P (Purple) lines: River, Y (Yellow), G (Green): (a) Research location. 
Data collection for early stage fish is carried out during high tide and daylight hours. The tool used to catch fish larvae is fish trap net larvae with a mesh size of $0.45 \mathrm{~mm}$ temporarily placed in the mangrove channel area.

- Abundance of Fish Larvae

The abundance of fish larvae which is defined as the number of fish larvae united in water volume is calculated using the formula:

$$
N=n / V_{t s r},
$$

Where:

$\mathrm{N}=$ abundance of fish larvae (ind / m3)

$\mathrm{n}=$ number of larvae enumerated

$\mathrm{Vtsr}=$ volume of filtered air $(\mathrm{Vtsr}=1 \times \mathrm{t} \times \mathrm{v})$

$1=$ the width of the larvae mouth opening

$\mathrm{t}=$ duration of meeting (minutes of withdrawal) (minutes)

$\mathrm{v}=$ speed of playback time (crane speed) (meters / minute)

- Diversity Index

An index of a collection of types of fish larvae used to determine the number of individuals between genera in a community. This value is calculated using the Shannon-Wiener index, the Shannon-Wiener Membership Index Formulation is based on the following equation:

$$
\mathrm{H}^{\prime}=\sum_{i=1}^{n} \mathrm{pi} \ln \mathrm{pi}
$$

Information:

$\mathrm{H}^{\prime}=$ Shannon-Wiener Diversity Index

$\mathrm{N}=$ total number of individuals in the community (ni)

$\mathrm{ni}=$ number of individual species or species $\mathrm{i}$

$\mathrm{pi}=$ proportion of the second individual species $(\mathrm{ni} / \mathrm{N})$

$\mathrm{i}=1,2,3, \ldots . ., \mathrm{s}$

$\mathrm{s}=$ number of genus $/$ species

- Domination Index

The dominance index to find out the dominant types of fish larvae is obtained using the following formula (Odum, 1994):

$$
\mathrm{D}=\sum_{i=1}^{s}(\mathrm{pi})^{2}=\sum_{i=1}^{n}\left(\frac{n i}{N}\right)^{2},
$$

Where:

$\mathrm{D}=$ dominance index

this $=$ number of individual genus $\mathrm{i}$ 
$\mathrm{N}=$ total number of individuals

pi $=$ proportion of individual species $\mathrm{i}$

$\mathrm{I}=1,2,3, \ldots, \mathrm{s}$

$\mathrm{s}=$ number of genus

- Simillarity Index

Simillarity is an illustration of the distribution of individuals from each species in the commotation of fish larvae. The uniformity index value $(\mathrm{E})$ is calculated based on the following equation:

$$
E=\frac{\mathrm{H}^{\prime}}{\mathrm{H} \text { maks }} \text { atau } E=\frac{\mathrm{H}^{\prime}}{\ln s},
$$

Where:

$\mathrm{E}=$ uniformity index

$\mathrm{H}^{\prime}=$ variation index

$\mathrm{S}=$ number of genus / species

The Simillarity Index (E) is used to find out the large number of each genus / species at the community level. Uniformity index value between $0-1$. E Value Loading 1 agrees to the distribution of individuals between types evenly (uniform) while Spelling Value 0 is considered to be an unequal distribution of individuals or there are types that are contradictory.

- $\quad$ Spatial Analysis

Spatial analysis was used to interpret the map of biological hotspots of fish larvae in Timbulsloko in this study the software used was QGIS software. The biological larvae hotspot are known from the relationship between fish larvae and oceanographic parameters, then from the value of the community structure (collection, dominance, uniformity and abundance can be used in accordance with the provisions of the initial stage fish distribution in an area in the temperature range, and salinity).

- $\quad$ PCA (Principal Component Analysis)

Principal Component Analysis (PCA) can be simply interpreted as a projection method to determine the maximum variability of a group of data (matrix) [7]. PCA is used to find linear combinations of environmental and biological parameters in maximum or minimal variation data with ordination techniques which project matrix dispersions from multidimensional data in a flat space. By reducing space, new axes are obtained which represent optimally from the majority of the variability of multidimensional matrix data so that relationships between characteristics and relationships between objects can be found. PCA divides the parameter correlation matrix into several components, then arranges the diversity of the relevant components from the largest on the axis of the main component to obtain spatial distribution of biological, physical and chemical parameters in a particular area. The linear correlation between the two parameters analyzed from the synthetic index is 
the variety of the two normalized parameters. This analysis is used to determine the distribution of aquatic bio-physicochemical parameters [7], [8]. Main Component Analysis uses the Euclidean distance index on the data. Euclidean distance relationship is based on the formula:

$$
D^{2}\left(i, i^{\prime}\right)=\Sigma\left(X i j-X i^{\prime} j\right)^{2}
$$

Where :

$\mathrm{i}, \mathrm{i}^{\prime}=$ two stations (on the line)

$\mathrm{j}=$ environmental parameters

The smaller the Euclidean distance between the 2 stations, the more bio-physicochemical characteristics between the two stations are similar, and vice versa. PCA calculations are carried out with the help of the $\mathrm{R}$ Studio statistical program package (https://www.datacamp.com/community/tutorials/pca-analysis-r).

\section{Results}

\subsection{Fish Larvae Collected}

\subsubsection{Fish larvae proportion}

Fish Larvae Caught The overall composition of fish larvae caught based on repeat sampling is presented in Figure 2.

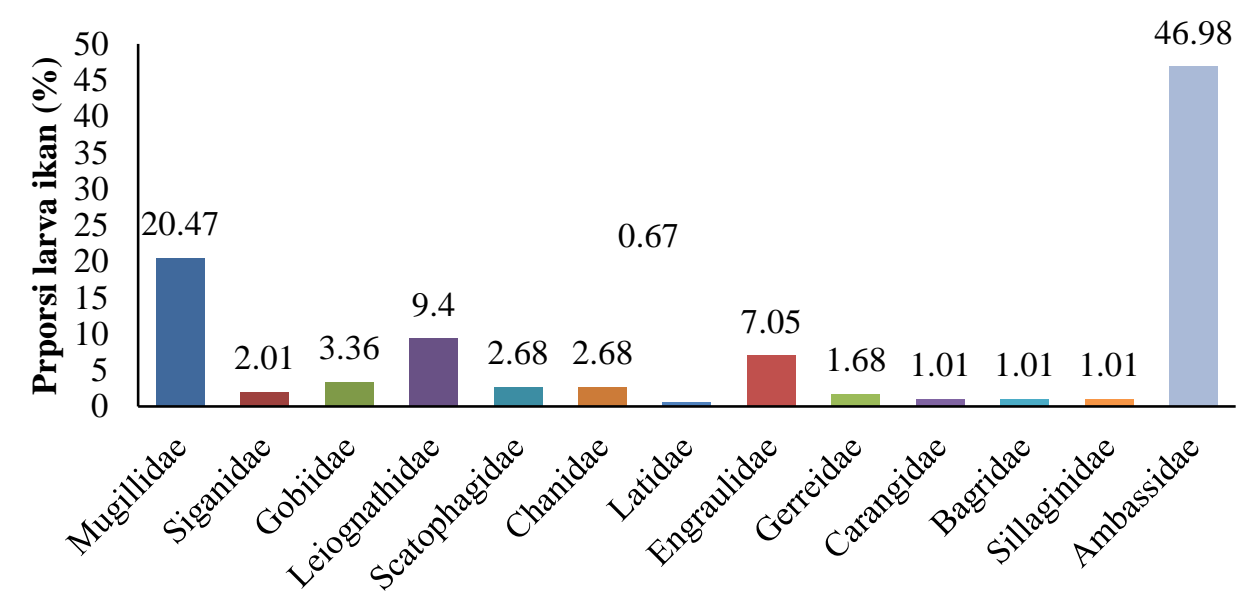

(a)

Figure 2. The composition of the types of fish larvae that are caught are Mugilidae, Siganidae, Gobiidae, Leiognathidae, Scatophagidae, Chanidae, Latidae, Engraulidae, Gerreidae, Carangidae, Bagridae, Sillaginidae, Ambassidae: (a) Fish larvae (\%).

Fish larvae caught in the Mangrove Conservation Area as much as ind / $\mathrm{m} 3$ consisting of 13 families. The composition of the types of fish larvae caught are Mugilidae, Siganidae, Gobiidae, Leiognathidae, Scatophagidae, Chanidae, Latidae, Engraulidae, Gerreidae, 
Carangidae, Bagridae, Sillaginidae, Ambassidae. The most caught types of fish larvae in each repetition are Ambassidae fish larvae. While the least caught species of fish larvae in each repetition are Carangidae, Bagridae, Sillaginidae fish larvae. The percentage of fish larvae that appear frequently is Mugilidae, Leiognathidae, Ambassidae. The Ambassidae family was caught at each point with an emergence percentage of $46.98 \%$. The least common fish larvae are the Carangidae, Bagridae, Sillaginidae families with an emergence percentage of only $1.01 \%$.

3.2. Aquatic Chemistry Physics Paremeter

Physics-Chemistry Parameters measured are temperature, $\mathrm{pH}$, salinity, brightness, depth, current velocity. The results of the measurement of Aquatic Chemical Physics Parameters are presented in Table 1.

Table 1. Aquatic Chemistry-Physics Parameters.

\begin{tabular}{|c|c|c|c|c|c|c|c|}
\hline \multirow[t]{2}{*}{ No. } & \multirow{2}{*}{$\begin{array}{c}\text { Titik } \\
\text { Sampel }\end{array}$} & \multicolumn{6}{|c|}{ Parameter } \\
\hline & & $\begin{array}{l}\text { Suhu } \\
\left({ }^{\circ} \mathrm{C}\right)\end{array}$ & Salinitas & Kecerahan & $\begin{array}{c}\text { Kedalaman } \\
(\mathrm{cm})\end{array}$ & $\mathrm{Ph}$ & DO \\
\hline 1 & A1LB1 & 32,5 & 30 & 6,8 & 45 & 8,23 & 6,9 \\
\hline 2 & J1LB3 & 32,2 & 24 & 34 & 76 & 8,13 & 6,9 \\
\hline 3 & A2G1 & 28,1 & 26 & 17,2 & 17,2 & 7,6 & 7,8 \\
\hline 4 & C1P1 & 29,3 & 28 & 67,8 & 199,6 & 7,14 & 8,4 \\
\hline 5 & $\mathrm{D} 2 \mathrm{P} 2$ & 28,6 & 25 & 33 & 190 & 7,33 & 7,9 \\
\hline 6 & E1P1 & 29,2 & 28 & 52,3 & 117 & 7,46 & 7,4 \\
\hline 7 & E1P1270 & 27,7 & 30 & 31,5 & 242 & 7,92 & 7,6 \\
\hline 8 & C1R1 & 28 & 30 & 42 & 197 & 8,05 & 7,7 \\
\hline 9 & D1R1 & 28,2 & 26 & 90 & 218 & 8,3 & 7,3 \\
\hline 10 & F1R1 & 28 & 28 & 88 & 233,5 & 8,28 & 7,5 \\
\hline 11 & B1R1 & 27,7 & 30 & 38 & 199 & 8,15 & 7,7 \\
\hline 12 & H1Y1 & 29,7 & 31 & 0 & 65 & 8,76 & 7,5 \\
\hline 13 & I1Y1 & 29,1 & 30 & 36,4 & 73 & 8,6 & 7,6 \\
\hline
\end{tabular}

The average water temperature ranges from $27.7-32.5^{\circ} \mathrm{C}$, the average value of water salinity obtained is $24-3030$, the average value of water brightness ranges from $0-90$, the average value of water depth ranged from $17.2-250 \mathrm{~cm}$, the average value of water $\mathrm{pH}$ ranged from 7.33-8.76, the mean value of $\mathrm{DO}$ waters ranged from 6.9 to 8.4 . 


\subsection{Community Structure of Fish Larvae}

The calculated community structure includes diversity ( $\mathrm{H}$ '), uniformity (E), and dominance (D). The results of the calculation of the diversity index, uniformity, and dominance values in the waters of Timbulsloko Village are presented in Table 2.

Table 2. Community Structure of Fish Larvae in the Waters of the Timbulsloko Village

\begin{tabular}{|l|l|r|r|r|r|}
\hline No. & Stasiun & \multicolumn{1}{c|}{$\begin{array}{c}\text { Larva ikan } \\
\text { Lelimahan }\end{array}$} & \multicolumn{1}{c|}{$\begin{array}{c}\text { Indeks } \\
\text { keanaragaman }\end{array}$} & $\begin{array}{c}\text { Indeks } \\
\text { Dominasi }\end{array}$ & $\begin{array}{c}\text { Index } \\
\text { keseragaman }\end{array}$ \\
\hline 1 & A1LB1 & 155.844 & 0.630 & 0.370 & 1.260 \\
\hline 2 & J1LB3 & 103.896 & 0.750 & 0.250 & 0.750 \\
\hline 3 & A2G1 & 324.675 & 0.633 & 0.367 & 1.003 \\
\hline 4 & C1P1 & 194.805 & 0.289 & 0.711 & 0.458 \\
\hline 5 & D2P2 & 428.571 & 0.590 & 0.410 & 0.935 \\
\hline 6 & E1P1 & 181.818 & 0.856 & 0.144 & 0.856 \\
\hline 7 & E1P1270 & 51.948 & 0.319 & 0.681 & 0.639 \\
\hline 8 & C1R1 & 116.883 & 0.392 & 0.608 & 0.784 \\
\hline 9 & D1R1 & 142.857 & 0.679 & 0.321 & 1.076 \\
\hline 10 & F1R1 & 168.831 & 1.138 & 0.138 & 1.138 \\
\hline 11 & B1R1 & 116.883 & 0.805 & 0.195 & 0.805 \\
\hline 12 & H1Y1 & 90.909 & 0.527 & 0.473 & 0.836 \\
\hline 13 & I1Y1 & 155.844 & 0.909 & 0.091 & 0.909 \\
\hline
\end{tabular}

The diversity index value at each sampling point is smaller than 1, so the diversity level is low. The uniformity index value at point A1LB1 is classified as a high level of uniformity. The highest Domination index value is located at point C1P1.

\section{Discussion}

The interaction between physical and biological parameters resulted in the distribution of abundance and diversity of fish larvae in the estuary area of tropical waters. Among the environmental variables (salinity, temperature, brightness, and DO) with regularity or irregularity in each of these variables that are fluctuating (always changing in each time), greatly determine how ecological sustainability in the estuary region [9], [10]. The fluctuating changes in environmental variables at night and during the day have differences as in the correlation analysis of Figure 3. 


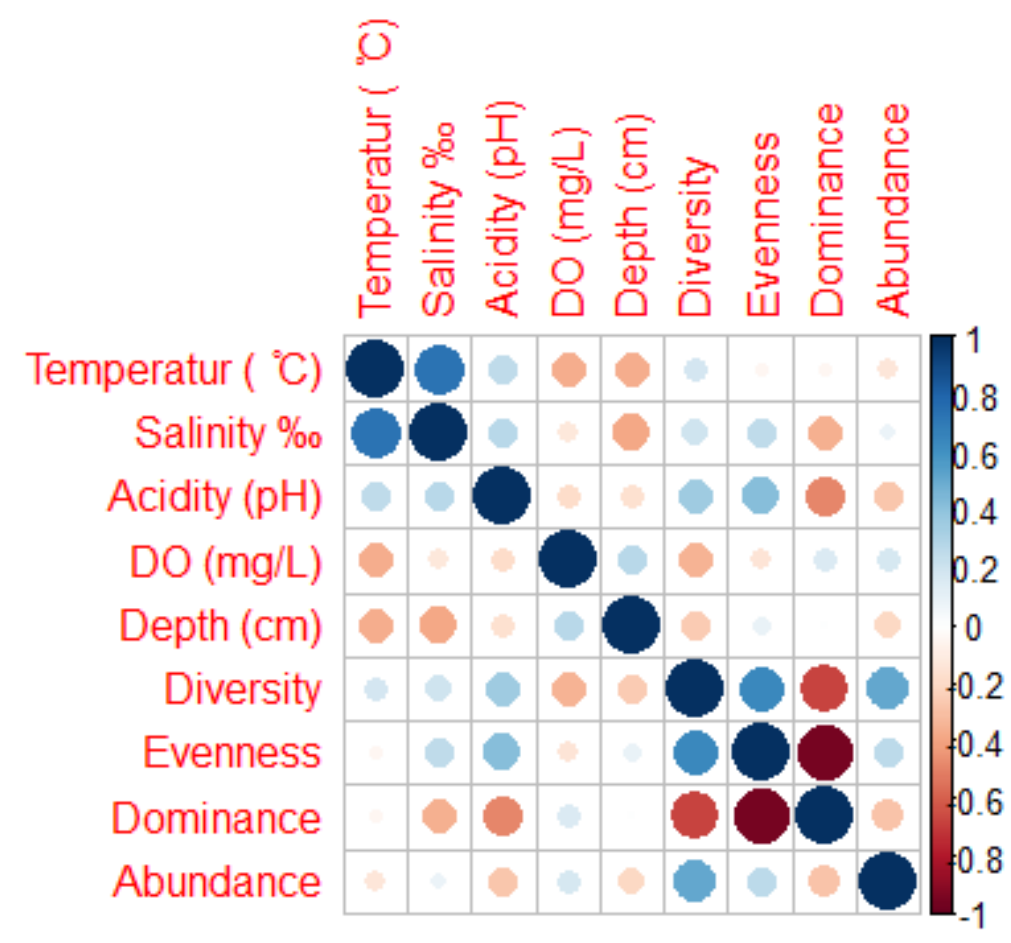

(a)

Figure 3. The relationship of physical chemistry parameters in a scale of values 1 to -1 : (a) Correlation analysis using R Studio [11].

Salinity and temperature are positively correlated, that is, when salinity increases, the temperature also increases and vice versa. In other variables $\mathrm{pH}$ correlates positively with salinity and temperature, but has a weak relationship. Diversity index and uniformity are positively correlated with temperature and salinity with weak relationships between variables. This study is in accordance with research conducted by [12], where the index of uniformity and diversity has the same tendency of relations. On the other hand there was a negative relationship between diversity index and dominance index in this study which was similar to the study of the Naaf river estuary. 


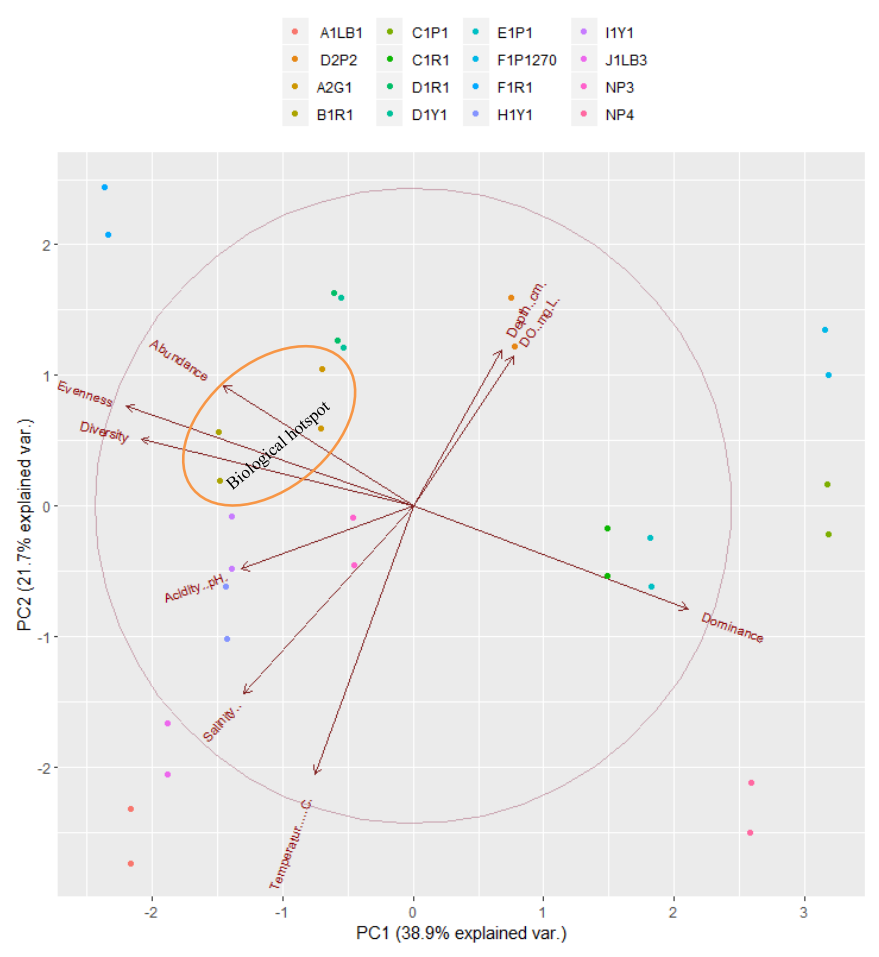

(a)

Figure 4. Euclidean distance shows the similarity of values at point D2P2 and A2G1: (a) Output from Principal Component Analysis.

D2P2 and A2G1 stations have similarities which are close to the values of $\mathrm{pH}$, Salinity, Uniformity Index and Diversity Index. This shows that there is an area with potential as an area of preference for fish larvae to survive. Besides that, it can be seen from the depth contour map and spatial vegetation that the D2P2 and A2G1 regions have the same regional contour pattern and vegetation type and are located in a straight line which indicates the influence of oceanogarafi parameters in determining the biological hotspot of fish larvae. The ecological similarity can also explain the traces of the mangrove habitat's fertility before the abrasion in Timbulsloko Village. 


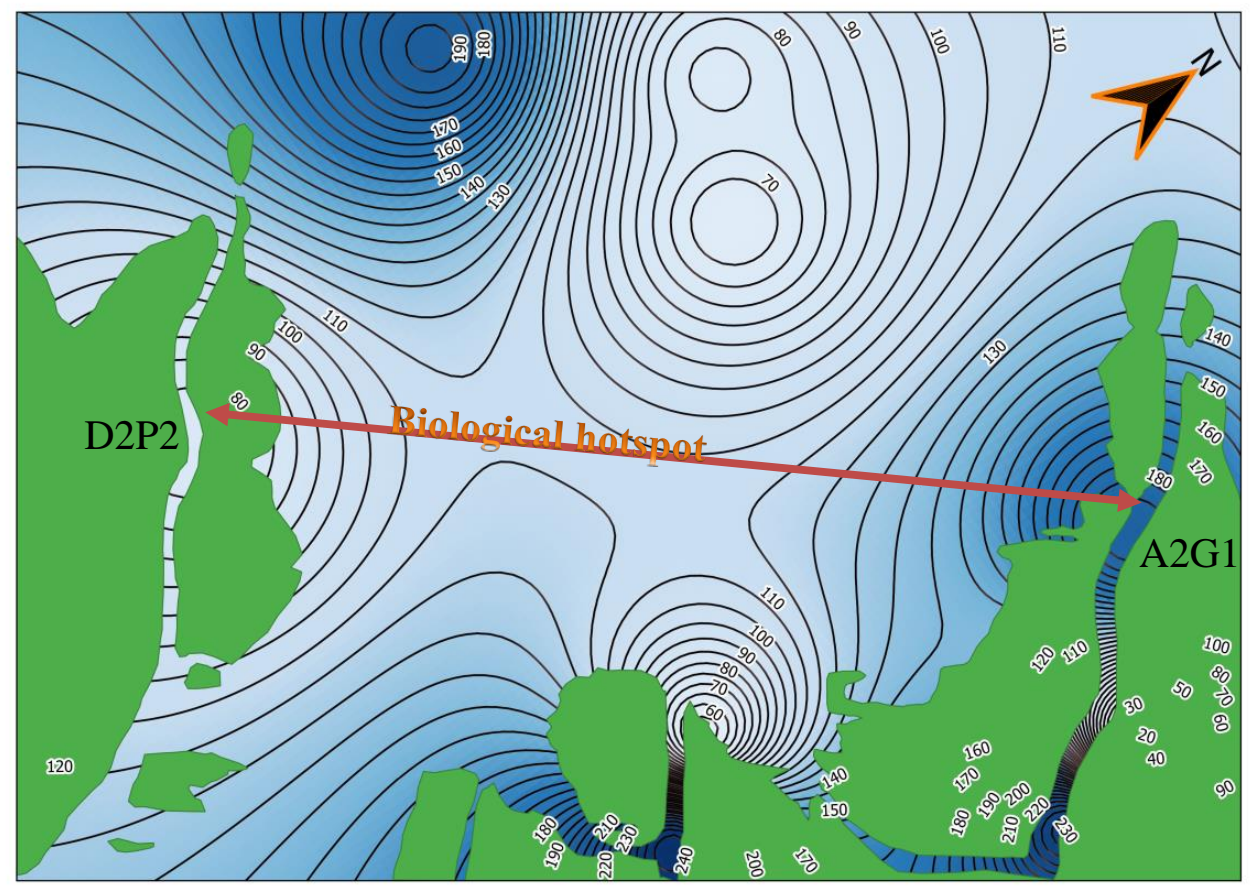

Figure 5. Estimated location of the Biological Hotspot.

\section{Conclusions}

The similarity of ecological habitat values at D2P2 and A2G1 points based on PCA analysis and the similarity of spatial contours from spatial depth interpolation indicate the biological hotspot in the mangrove waters of Timbulsloko Village.

\section{References}

[1] P. Petitgas, M. Woillez, M. Doray, and J. Rivoirard, "A Geostatistical Definition of Hotspots for Fish Spatial Distributions," Math. Geosci., pp. 65-77, 2016.

[2] R. Vinícius, S. Santos, S. Ramos, A. Cristina, and T. Bonecker, “Environmental control on larval stages of fish subject to specific salinity range in tropical estuaries," Reg. Stud. Mar. Sci., 2017.

[3] M. Huxham, E. Kimani, and J. Augley, "Mangrove fish : A comparison of community structure between forested and cleared habitats," vol. 60, pp. 637-647, 2004.

[4] C. T. Perry and A. Berkeley, "Intertidal substrate modification as a result of mangrove planting: Impacts of introduced mangrove species on sediment microfacies characteristics," Estuar. Coast. Shelf Sci., vol. 81, no. 2, pp. 225-237, 2009.

[5] Hawati et al, "Waves Induce Sediment Transport at Coastal Region of Timbulsloko Demak," Earth Environ. Sci., vol. 55, 2017.

[6] A. Ismanto, M. Zainuri, S. Hutabarat, and D. N. Sugianto, "Sediment Transport Model In Sayung District, Demak," vol. 012007, pp. 3-9.

[7] K. Kafadar, J. R. Koehler, W. N. Venables, and B. D. Ripley, "Modern Applied Statistics with S-Plus," Am. Stat., vol. 53, no. 1, p. 86, 2006.

[8] M. Taufik, "Distribusi Dan Kelimpahan Larva Ikan Di Perairan Laguna Pulau Pari dan Sekitarnya," 
Institut Pertanian Bogor, 2012.

[9] S. J. M. Blaber, Tropical Estuarine Fishes. Cleveland, Queensland Australia: Blackwell Science, 2000.

[10] A. K. Whitfield, "Ichthyofaunal assemblages in estuaries : A South African case study," pp. 151-186, 1999.

[11] M. Friendly, “Corrgrams: Exploratory displays for correlatigon matrices,” Am. Stat., vol. 56, no. 4, pp. 316-324, 2002.

[12] M. S. Hossain, N. G. Das, S. Sarker, and M. Z. Rahaman, "Fish diversity and habitat relationship with environmental variables at Meghna river estuary , Bangladesh," Egypt. J. Aquat. Res., vol. 38, no. 3, pp. 213-226, 2013. 